\title{
Download
}

UDC 502.171:502.521 https://doi.org/10.17721/2308-135X.2021.61.52-58

Kalko Andrii, Doctor of Geographical Sciences, Professor Internetional university of economics and humanities academician Stepan Demianchuk, Rivne, Ukraine, e-mail: edissey@meta.ua

Melniychuk Michaylo, candidate of geographical sciences, associate professor Lesya Ukrainka Volyn National University, Lutsk, Ukraine

Melniychuk Maksim Lesya Ukrainka Volyn National University, Lutsk, Ukraine

Akhmedov Bogdan Lesya Ukrainka Volyn National University, Lutsk, Ukraine

Yaromenko Oksana, candidate of geographical sciences, associate professor Internetional university of economics and humanities academician Stepan Demianchuk, Rivne, Ukraine, , e-mail: yaromenko_ov@ukr.net

\section{AGRICULTURAL DEVELOPMENT OF LANDS OF VOLYN REGION}

The aim is to determine the degree of agricultural development of the lands of Volyn region.

Method. The agricultural development of the lands of the Volyn region by administrative-territorial districts is determined. General scientific and static methods, methods of system and structural analysis, comparative geographical and graphic methods are applied. 
Regional statistics were processed. The formulas for determining the agricultural development of lands, coefficients of plowed lands and plowed agricultural lands are given.

Results. Agricultural development of the territory is defined as the ratio of the area of agricultural land to the total land area, excluding areas under water and swamps. As a result of calculations we determined that the highest indicator of agricultural land development of Volyn region is $78-80 \%$, and is the highest for Rozhysche, Lutsk and Gorokhiv districts of the region, the degree of agricultural land development is the lowest for Kamin-Kashirsky, Lyubeshiv, Manevychi and Shanevytsia. The average value of the coefficient of agricultural development for the territory of Volyn region is $56.6 \%$. or the entire territory of Volyn region, the coefficient of plowing of the land territory is $38.13 \%$. The highest percentage of plowed lands of the region is typical for the southern forest-steppe regions of the region. Based on the analysis of the plowing coefficient, the territory of Volyn region is assessed as «conditionally favorable». Plowing of agricultural lands in modern conditions characterizes the intensity of agricultural production and ecological tension of the territory. The highest coefficient of plowing of agricultural lands is typical for the territories of Gorokhiv district (88.34\%), Lutsk (86.48\%), Lokachyn (85.34) and Ivanychiv (82.7) districts, the lowest coefficient of plowing of agricultural lands is observed in the territories of Lyubeshivsky Ratnivsky and Lyubomlsky administrative-territorial districts of Volyn region. The average plowed agricultural land for the territory of Volyn region is $64.72 \%$. Thus, for forest-steppe areas this indicator is higher. Thus, for forest-steppe areas this indicator is higher.

Scientific novelty. The typology of administrative-territorial districts of Volyn region according to the degree of agricultural development and the coefficient of plowing of lands (including agricultural lands) is carried out.

Practical significance. The results of the studies reveal the condition of lands in the Volyn region. Can be used to determine the potential productivity of land resources in the region. Determining the level of transformation and rational efficiency of their use.

Key words: land, agricultural lands, agricultural development, plowing, Volyn region. 
1. Pavlov V. I., Fesina Yu. H., Zaremba V. M., Mazuryk S. M. Determinatsiia silskohospodarskykh zemel na rynku nerukhomosti: monohrafiia. Lutsk: Nadstyria, 2006. 364 s.

2. Pavlovska T. S. Struktura zemelnykh uhid v landshaftno-ekolohichnii orhanizatsii terytorii Volynskoi oblasti. Heopolytyka y эkoheodynamyka rehyonov. 2014.. № 2. S. 697-704.

3. Polianskyi S. V., Kniazkova T. O. Otsinka efektyvnosti vykorystannia i zberezhennia zemelnykh resursiv Volynskoi oblasti. Ekonomichni nauky. Seriia «Ekonomichna teoriia ta ekonomichna istoriia»: Zbirnyk naukovykh prats LNTU. Lutsk : RVV LNTU, 2011. Vyp. 8 (32). S. 292-300.

4. Prohnozuvannia vykorystannia zemel: metod. vkazivky dlia vykonannia laboratornykh robit za temoiu: «Analiz ta prohnozuvannia vykorystannia zemelnykh resursiv» / ukl.: M.I. Bidylo, V.V. Masliennikova, L.V. Horbatova. KhNAU. Kharkiv, 2016. 38

5. Statystychnyi shchorichnyk: Volyn - 2016. Holovnoho upravlinnia statystyky u Volynskii oblasti. Za red. M. I. Motyl. Lutsk. 2017. 569 s.

6. Strishenets O., llin L., Pavlov K. Zasady efektyvnoho zemlekorystuvannia Volynskoi ta Rivnenskoi oblastei: rehionalnyi aspekt. Rehionalna ekonomika ta ekonomika pryrodokorystuvannia. K., 2016. S. 52-59.

7. Sukhyi P. O., Darchuk K. V. Suchasnyi stan vykorystannia zemel silskohospodarskoho pryznachennia Ivano-Frankivskoi oblasti. Naukovyi visnyk Volyn. nats. un-tu im. Lesi Ukrainky : heohrafichni nauky. № 9. Lutsk : Volynskyi natsionalnyi universytet, 2011. S. 70-77. 